\title{
The effect of halal tour, word of mouth, price and social media on visiting decisions to non muslim countries at PT.Tour and Travel Antavaya Palembang
}

\author{
Desfika Rusmalita Utami ${ }^{1)}$, Mismiwati ${ }^{2)}$, Aryanti ${ }^{3)}$ \\ ${ }^{1,2,3)}$ The Faculty Of Islamic Economic And Business, UIN Raden Fatah Palembang \\ Corresponding author: mismiwati_uin@radenfatah.ac.id
}

\begin{abstract}
This study aims to determine the effect of the halal tour, word of mouth, price and social media on visiting decisions to non-muslim countries at PT.Tour and Antavaya Travel Palembang. The source of data is primary data through questionnaire. The sample of this study was 110 respondents, technique with purposive sampling method. This research used quantitative methods. with the multiple regression analysis method. The research variables consist of independent variables: 1.Halal Tour, 2. Word of mouth 3.Price 4.Social Media. While the dependent variable is the decision to visit. The result showed a halal tour didn't significantly influence the visiting decision. Word of mouth, price, and social media are significantly influence on visiting decision.
\end{abstract}

Keywords: Halal Tour, Word of Mouth, Price, Social Media and Decision to Visit

\section{Introduction}

Halal tourism is part of the tourism industry that aimed at Muslim tourists. Tourist services in halal tourism refer to Islamic rules. The basic things that are needed by Muslim tourists are Halal food, worship facilities, transportation services, accommodation services, facilities in the month of Ramadan and human resources.

The development of halal tourism trends and see the potential of halal tourism then many non-Muslim countries are competing in developing the halal tourism business. The decision to visit a tourist destination in a non-Muslim country is indeed what is needed by most tourists with consideration of the ease of finding halal food, worship facilities, accommodation and competent human resources in serving Muslim guests. According to Miftah El Fikri research (2019) halal tour significantly influence on visiting decision. This research also explains that good promotion will increase the decision to visit. This is in line with research by Anis Setiyorini (2018) word of mouth and social media significantly influence visiting decisions. Price is also one factor that is highly considered in making a decision, so this is in line with research by Adriel Jordan ( 2018) price significantly influence on visiting decision.

\section{Method}

This research used quantitative methods, The population in this study were all consumers of PT.Tour dan Travel Antavaya Palembang from 2016-2019. The source of data is primary data through questionnaires. The questionnaires were distributed using a Likert scale to measure respondent's perceptions. The sampling technique with a non-probability sampling technique with a purposive sampling method that is taking samples with criteria or characteristics of consumers who have used the services of PT.Tour dan Travel Antavaya Palembang in 2019, Muslim tourists who have visited non-Muslim countries. The size of the sample taken using the formula Hair et al, indicators multiplied by 5-10. The sample of this study was 110 respondents. Technical data analysis using SPSS to determine the influence of halal tour, word of mouth, price and social media on visiting decisions.

\section{Result}

Based on the results of this study, the information obtained that Muslim tourists are mostly tourists who are still in their productive age 16-25 years old (42,7\%) and 26-35 years old (42,7\%), Muslim tourist work is dominated by others with the number $(35,5 \%)$ consisting of housewives, college students and students. Dominant respondents have income Rp. $3.100 .000-\mathrm{Rp}$. 6.000 .000 is equal to $(38,2 \%)$. The aim of most Muslim tourists to leave was to travel (56.4\%). And most of Palembang Muslim tourists get information about PT.Tour and Travel Antavaya Palembang from friend is equal to (53.6\%). With the highest intensity of departure the first time $(51.8 \%)$ Based on the results of the hypothesis test, the results obtained are:

Table 1. Results of The Hypothesis Test 


\begin{tabular}{|c|c|c|c|c|c|c|}
\hline \multicolumn{7}{|c|}{ Coefficients } \\
\hline & \multirow[t]{2}{*}{ Model } & \multicolumn{2}{|c|}{ Unstandardized Coefficients } & \multirow{2}{*}{$\begin{array}{c}\begin{array}{c}\text { Standardized } \\
\text { Coefficients }\end{array} \\
\text { Beta }\end{array}$} & \multirow[t]{2}{*}{$\mathbf{T}$} & \multirow[t]{2}{*}{ Sig. } \\
\hline & & B & Std. Error & & & \\
\hline \multirow{5}{*}{1} & (Constant) &,- 202 &, 308 & &,- 655 & 514 \\
\hline & RATA2_X1 &, 057 & ,078 &, 046 & ,723 & ,472 \\
\hline & RATA2_X2 &, 171 & ,080 &, 154 & 2,137 &, 035 \\
\hline & RATA2_X3 & ,591 &, 101 &, 540 & 5,863 &, 000 \\
\hline & RATA2_X4 & ,239 & ,086 & ,216 & 2,771 &, 007 \\
\hline
\end{tabular}

a. Dependent Variable: RATA2_Y

Source : result of processing with SPSS (2019)

So it can be written as follows:

$$
Y=-0,202+0,57 X 1+0,171 X 2+0,591 X 3+0,239 X 4
$$

information :

$\begin{array}{ll}\mathrm{Y} & \text { : visiting decision } \\ \alpha & \text { : constant } \\ \mathrm{b} 1, \mathrm{~b} 2, \mathrm{~b} 3, \mathrm{~b} 4 & \text { : the coefficients of each variable } \\ \mathrm{X} 1 & \text { : halal tour } \\ \mathrm{X} 2 & \text { : word of mouth } \\ \mathrm{X} 3 & \text { : price } \\ \mathrm{X} 4 & \text { : social media }\end{array}$

As for the test coefficient of determination (R2) is

Table 2. Coefficient of Determination Model Summary

\begin{tabular}{lcccc}
\hline Model & R & R Square & Adjusted R Square & $\begin{array}{c}\text { Std. Error of the } \\
\text { Estimate }\end{array}$ \\
\hline 1 &, $859^{\text {a }}$ &, 738 &, 728 &, 27727 \\
\hline a. Predictors: (Constant), RATA2_X4, RATA2_X1, RATA2_X2, RATA2_X3 \\
Source : result of processing with SPSS (2019)
\end{tabular}

Based on table 2 was obtained adjusted $\mathrm{R}$ square value 0,728 , this means the amount of influence halal tour (X1), word of mouth (X2), price (X3) and social media (X4) on visiting decision (Y) by $72,8 \%$ while the remaining $27,2 \%$ influenced by other factors not examined in this study.

Table 3. Simultaneous ANOVA

\begin{tabular}{llccccc}
\hline & Model & Sum of Squares & Df & Mean Square & F & Sig. \\
\hline \multirow{2}{*}{1} & Regression & 22,694 & 4 & 5,674 & 73,796 &, $000^{\mathrm{b}}$ \\
& Residual & 8,072 & 105 &, 077 & & \\
& Total & 30,766 & 109 & & & \\
\hline
\end{tabular}

a. Dependent Variable: RATA2_Y

b. Predictors: (Constant), RATA2_X4, RATA2_X1, RATA2_X2, RATA2_X3

Source : result of processing with SPSS (2019)

Based on table 3 , the $F$ value is 73,796 with a significance of $0,000<0,5$ which means that the variable $\mathrm{X} 1, \mathrm{X} 2, \mathrm{X} 3, \mathrm{X} 4$ significant on $\mathrm{Y}$. so the halal tour, word of mouth, price and social media significantly influences on visiting decision to non-Muslim countries at PT.Tour and Travel Antavaya Palembang.

Table 4. Significant Test

\begin{tabular}{llccc}
\hline & Model & T hitung & T table & Sig. \\
\hline & (Constant) &,- 655 & 1,659 &, 514 \\
& RATA2_X1 &, 723 & 1,659 &, 472 \\
1 & RATA2_X2 & 2,137 & 1,659 &, 035 \\
& RATA2_X3 & 5,863 & 1,659 &, 000 \\
& RATA2_X4 & 2,771 & 1,659 &, 007 \\
\hline
\end{tabular}

Source : result of processing with SPSS (2019) 
In table 4 we can see $t$ value and the significance of each independent variable. In the halal tour variable has a calculated value of 0,723 which is smaller than t table $1,659(0,723<1,659)$. With a significance of $0,472>0,05$ That is means halal tour has no effect and didn't significant to decision of visiting. It is because there are still doubts from the people of Palembang to visit non-Muslim countries, and they are not too concerned with the concept of halal tourism offered, they are only focused on the tourist destination that will be visited.

The variable word of mouth has a calculated value of 2,137 > from t table 1,659 $(2,137>1,659)$ With a significance of $0,03<0,05$ meaning that the word of mouth has a positive and significant effect on visiting decisions. This indicates that communication is very important because when people have ever used a service PT.Tour dan Travel Antavaya Palembang and sharing their experiences that will be more trusted by their relatives and friends.

Variable price has a calculated value of 5,863 > from $t$ table $1,659(5,863>1,659)$ With a significance of $0,00<0,05$ meaning that price has a positive and significant effect on visiting decisions. Price is a very influential thing in creating a visiting decision, meaning that if the price given by PT. Tour and Travel Antavaya Palembang is relatively affordable, it will encourage the decision to visit non-Muslim countries at PT. Tour and Travel Antavaya Palembang.

Variable social media has a calculated value of $2,771>$ from t table $1,659(2,771>1,659)$ With a significance of $0,00<0,05$ meaning that social media price has a positive and significant effect on visiting decisions. Considering that almost all Indonesian people from children to adults have social media accounts then promotion through social media is the most effective way to attract tourists to make a decision to visit a non-Muslim country.

\section{Conclusion}

Based on the results of the study can be concluded : 1) halal tour didn't significantly influence on decision to visit because there are still doubts from Muslim tourists about non-Muslim countries that will be visited; 2) word of mouth significantly influence on decision to visit, this means promotion with word of mouth is important because recommendations from friends are more trustworthy; 3) price significantly influence on decision to visit, prices play an important role for tourists in making visiting decisions because when the price offered is in accordance with the facilities provided, tourists will be interested in making a decision to visit; 4) social media significantly influence on decision to visit, this means that promotion through social media is very effective because information will be more quickly spread through by social media; 5) halal tour, word of mouth, price and social media are significantly influence on decision to visit, this is due to the quality halal tour, word of mouth was delivered well, an affordable price, and promotions that are easily accessible to the public then together will be influence the decision to visit non-Muslim countries.

\section{References}

Adib, Helen Sabera. 2015. Metodologi Penelitian. Palembang: NoerFikri.

Adriel, Jordan Anggono Sunarti. 2018. Pengaruh Harga dan Word of Mouth Terhadap Keputusan Berkunjung Jurnal.Vol.61 No.3

Anis, Setiyorini.2016. Pengaruh Promosi lewat media sosial, word of mouth dan daya tarik wisata terhadap keputusan berkunjung wisatawan objek wisata gunung beruk karangpatihan Balong.Jurnal Sekolah Tinggi Pariwisata

Basuki, Agus Tri dan Prawoto, Nano. 2017. Analisis Regresi dalam Penelitian Ekonomi dan Bisnis. Jakarta: Rajawali Pers.

J.F. Hair, Multivariate Data Analysis. 2006. Edisi 5, (Semarang: Gramedia Pustaka Utama)

Juliandi, Azuar, dkk. 2014. Metodelogi Penelitian Bisnis. (Medan: UMSU Press Medan)

Kotler, Philip dan Armstrong, Gary. 2006. Prinsip-Prinsip Pemasaran Edisi 12 (Jilid 1). Jakarta: Erlangga

Kotler, Philip dan Keller, Kevin Lane. 2017. Manajemen Pemasaran, edisi kedua belas. PT. Macanan Jaya Cemerlang.

Kotler, Philip dan Keller Kevin Lane. 2008. Manajemen pemasaran edisi ketiga belas jilid 1. Jakarta : Penerbit erlangga

Kotler, Philip. 2012. manajemen pemasaran: analisis perencanaan, implementasi dan pengendalian edisi ke sebelas. Jakarta : PT. indeks kelompok gramedia

Kotler Philip dan keller Kevin lane. 2008. manajemen pemasaran edisi ketiga belasjilid 2. Jakarta : penerbit erlangga

Miftah El-Fikri dan Dewi Nurmasari. 2019. Kajian Destinasi Wisata Halal Kota Medan dalam Persepsi Pemasaran Wisata. Jurnal.Vol.11 No.1, Juni

Misbahudin dan Iqbal, Hasan. 2014. Analisis Data Penelitian Dengan Statistik. Edisi Ke-2. Jakarta: Bumi Aksara.

Noor, Juliansyah 2011. Metodologi Penelitian, edisi pertama ( Jakarta: Prenada Group)

Peter, J Paul dan Olson, Jerry C. 2016. Perilaku Konsumen dan Strategi Pemasaran,edisi 9. Jakarta: Salemba Empat. 
Priyatno, Duwi. 2010. Paham Analisis Statistik Data Dengan SPSS. Yogyakarta: Mediakom. Saparini, Hendri dkk. 2018. Bisnis Halal: Teori Dan Praktik. Depok :PT Raja Grafindo Persada Sugiyono. 2016 Metode Penelitian Kuantitatif, Kualitatif, Dan R\&D, Cetakan ke23. Bandung: Alfabeta. Tjiptono, Fandy. 2014. Pemasaran Jasa: prinsip penerapan dan penelitian. Yogyakarta: Andi. Triastuti, endah dkk.2017.kajian dampak penggunaan media sosial bagi anak dan remaja. depok, 